\title{
CUSTOMER SATISFACTION AND LOYALTY: A STUDY OF INTERRELATIONSHIPS AND EFFECTS IN NIGERIAN DOMESTIC AIRLINE INDUSTRY
}

\author{
Rahim A. Ganiyu \\ Department of Business Administration, University of Lagos, Lagos, Nigeria \\ abdulrahimajao@yahoo.com
}

\begin{abstract}
The debate concerning the interrelationships and effects between customer satisfaction and loyalty has been tossed back and forth, without a consensus opinion. This study examines the linkages between customer satisfaction and loyalty in Nigerian domestic airline industry. The study adopted correlation research design to elicit information via questionnaire from 600 domestic air passengers drawn through convenience sampling technique. The data obtained from the respondents were analysed with Pearson correlation analysis, linear regression, and One-way analysis of variance. Based on 383 completed data, the results provide support for the association and influence of customer satisfaction on customer loyalty. The study also found out that frequent air travelers displayed more loyalty tendency towards airline carriers compared to non-frequent air passengers. On the basis of aforementioned findings, the study concludes that customer satisfaction is extremely important in building and enhancing customer loyalty. Therefore, airline carriers should implement strategies that will guarantee long-term relationship with air travellers by offering service quality that will meet and exceeds their expectations and by extension customer satisfaction.
\end{abstract}

Keywords: customer satisfaction, loyalty, loyalty programme, service failure, domestic air travel, airline industry.

JEL classification: M30, M31.

\section{Background to the study}

Across the globe, the airline industry is a progressively growing segment of most economy and it has developed rapidly to become one of the most common means of travel. Specifically, airline industry facilitates economic development, world trade, tourism and global investment among other numerous benefits. Nonetheless, the importance of this industry is not only related with the combined significance of connectivity, but its contribution to the growth of numerous businesses which depend on airlines, such as hotels businesses, car hire operators, tourism etc. Currently, customer satisfaction with the service quality offered by airlines has become the most significant factor for success and survival in the airline industry. Customer satisfaction, according to Oliver (1997) is derived from the Latin word Satis (enough) and Facere (to do or make). In general, satisfaction is an internal view which offshoot from customers own experience of a consumption or service experience. Although the connection between customer satisfaction and company success has traditionally been tied to faith, and numerous satisfaction studies have supported this position (Hill and Alexander, 2000). Notwithstanding the aforementioned position, customer satisfaction has always been considered a vital business goal because of its crucial role in the formation of customer's desire for future purchase or tendency to buy more (Mittal and Kamakura, 2001).

Customer satisfaction, according to Pizam and Ellis (1999) refer to psychological notion that encompasses the feeling of comfort and pleasure that emanates from obtaining what one 
hopes for and expects. According to Kotler (2001: 58) "satisfaction is the feeling of pleasure or disappointment resulting from comparing the performance (or outcome) of a product or service perceived quality in relation to the buyer's expectation". However, in spite of the significance of customer satisfaction, many firms still experience a high level of customer switching despite been satisfied (Oliver, 1997; Taylor, 1998). This scenario has prompted a number of academics such as Jones and Sasser (1995), Reichheld (1996) and Egan (2004) to condemn the focus of attention on customer satisfaction and appeal for a paradigm shift to the pursuit of loyalty as a strategic business objective.

No doubt, the quality of service offered to air passengers is crucial for enhancing customer satisfaction (Gilbert and Wong, 2003; Rahim, 2015). Likewise, customer satisfaction is pivotal to loyalty formation. For instance, Reichheld and Sasser (1990) discover that loyal customers are keen to (1) re-buy products despite attractive competitive alternatives that might propel them to try out competing products, (2) commit substantial amount of money on firm's product line and service, (3) endorse and promote the firm's goods or services to other customers, and (4) offer the firm truthful feedback as regards the performance of their products/services. According to Too, Souchon, and Thirkell (2001), loyalty refers to commitment to rebuy the favorite product or service in the future, despite situational and marketing efforts which can alter the behaviour. To a substantial number of researchers, loyalty is strongly connected to customer repeat patronage and retention (Too et al, 2001; Samaha, Palmatier and Dant, 2011).

\section{Statement of the problem}

Passengers loyalty is what all airlines seek, and retaining customers imply lesser costs (compared with that of attracting new ones), particularly in such a time of economic depression leading to declining demand for air transportation and increasingly competitive markets. No doubt, one of the most vital issues that have greater influence on loyalty formation is creating a good flight experience (quality of service). The inherent characteristics of airline services have lent themselves to a relationship marketing tactic, however, several customer-related approaches of airlines focus on customer loyalty initiatives which increase short-term sales instead of focusing on long-term quality relationships between the airline operators and air travellers (Bejou and Palmer, 1998). Therefore, for airline operators to balance their short-term and long-term business objectives, they must devise strategies to deliver their services more satisfactorily than their competitors (Nadiri, Hussain, Ekiz, and Erdogan, 2008; Rahim, 2016a). A remarkable service experience, no doubt will enhance customer satisfaction, builds positive emotions and customer loyalty towards the service provider. Rahim (2015) observes that perceived service quality of domestic airline operators in Nigeria has generally been adjudged to be poor; consequently, the level of passengers' satisfaction and loyalty is low. However, to a dissatisfied air passengers', the only available option is to switch to alternative airline as refund is impossible once the flight trip has been accomplished. The immediate consequence of this scenario is negative word of mouth communication from customers that experience bad flight experience and this will lead to a devastating effect such as loss of revenue, customer's complaints etc.

A review of extant literature related to airline industry revealed that the relationship between customer satisfaction and loyalty has generated a lot of debate and controversy. To date, the controversy is unsettled. Likewise, the claim that customer satisfaction leads to loyalty appears less convincing to many researchers (Rahim, Ignateous, and Adeoti, 2012; Egan, 2004; Pritchard and Silverstro, 2005). Similarly, some scholars have reported instances where despite improving customer satisfaction level, many firms still experience challenges in enhancing their profitability (Timothy, Bruce, Lerzan, Tor, and Jay, 2007; Tim, Lerzan, Alexander, and Luke, 2009). Despite the significance of the above-mentioned issues, researchers have paid scant attention regarding the subject matter in the context of the 
Nigerian airline industry. Against the aforementioned backdrops, this study seeks to achieve the following objectives: (1) to study the relationship between customer satisfaction and loyalty in Nigerian domestic airline industry, (2) to evaluate whether flight frequency is related to passengers loyalty in Nigerian domestic airline industry.

\section{Research hypotheses}

The following relationships were hypothesized.

1. There is no significant relationship between customer satisfaction and loyalty in Nigerian domestic airline industry.

2. Compared with infrequent travellers, frequent air passengers are not likely to display more loyalty tendency in Nigerian domestic airline industry.

\section{Theoretical and literature review}

\section{Confirmation and disconfirmation theory of satisfaction}

There are several theoretical approaches to explain the relationship between disconfirmation and dissatisfaction as the framework for customer satisfaction theory. Some of these approaches are variants of the consistency theories and they focus on the nature of the process of matching and comparing the consumer's post-usage behaviour (Peyton, Pitts and Kamery, 2003). Foremost among these approaches are: the theory of assimilation, the theory of contrast, the theory of assimilation-contrast, the theory of negativity, and the theory of hypothesis testing. Adee (2004) maintains that numerous theories have been used to comprehend the process through which customers form satisfaction judgments. These theories according to him can be broadly classified under three groups: expectancy disconfirmation, equity, and attribution. Drawing on Helson (1964) adaptation level theory, Oliver (1977, 1980) develops expectation-disconfirmation paradigm (EDP) as a foundational theory for the assessment of customer satisfaction. The fundamental principle of EDP model is that, customer satisfaction is connected to the magnitude and direction of the disconfirmation experience (Oliver, 1980).

According to Paterson (1993), disconfirmation represents the gap between consumer pre-purchase expectations and perceived performance of the product or service. Which suggests that consumers buying decision is contingent on prior expectations about the expected performance, which form the yardstick for evaluating product or service performance. Hence, if the assessment meets consumer prior expectation confirmation occurs which leads to satisfaction. On the other hand, disconfirmation arises where there is a discrepancy between expectations and performance which causes dissatisfaction (Oliver, 1997).

Similar to the instance of SERVQUAL model, scholars have questioned the validity of the expectancy-disconfirmation model. Miller (1977) notes that customers elicited several different types of expectations (ideal, minimum, predicted, and normative performance), which may be problematic to comprehend and may explain significant variations in the strength of expectations relationship with other concepts in the satisfaction model. Another inadequacy of the EDP model is that post-purchase evaluations may not directly relate to original expectations, as such consumers may demonstrate satisfaction or dissatisfaction in some occasions where expectations never occurred (McGill and lacobucci, 1992). Correspondingly, lacobucci, Grayson, and Ostrom (1994) document another drawback of the EDP model which accentuates that customers will appraise a service favourably, as long as it meet or exceeds their expectations. Contrary to this claim, in a context where customers are manipulated to purchase a low-grade or less desirable brand due to scarcity of their preferred brand, then consumers may not automatically experience disconfirmation of a pre-experience assessment. Based on the aforementioned criticisms, a number of customer satisfaction theories have been advocated namely: value-precept theory, 
evaluative congruity model (or the social cognition model) among others to address the shortcomings of the EDP model.

\section{Towards a definition of customer satisfaction}

Customer satisfaction is a construct that has appeared in many fields of study and has been central to the marketing concept for several decades. The process of appraising customer expectations with the product or service's performance is the heart of satisfaction development and this process has conventionally been labeled as the 'confirmation/disconfirmation' (Vavra, 1997). Thus, if perceived performance is less than expected, assimilation will occur, but if perceived performance varies from expectations significantly, contrast will occur, and the gap in the perceived performance will be inflated (Vavra, 1997). The performance of a company in terms of the quality of its product/services leads to customer satisfaction (Huang and Feng, 2009). Generally, satisfaction can be observed by subjective factors (i.e. customer needs, emotions) and objective factors (e.g. product and service attributes). By and large, satisfaction is an attitude molded by the customer to compare their pre-purchase expectations to their subjective perceptions of the performance of the product or service (Oliver, 1980).

According to Yi (1990), customer satisfaction refers to collective outcome of perception, evaluation and the resulting psychological reactions to the consumption experience with a product/service. Chang, Wang, and Yang (2009) defined customer satisfaction as a psychological response or an evaluation of emotions from the customer. According to Garbarino and Johnson (1999) and Gronholdt, Martensen, Kristensen (2000), satisfaction is the outcome or assessment of what the customer initially expected and what they actually experienced during use and consumption of the product/service. Giese and Cote (2002) observe that there is no universal definition of customer satisfaction; hence, they view it as a recognised form of response (cognitive or affective) that relates to a particular context (e.g. a purchase experience and/or the related product) and arises at a certain time (i.e. post-purchase, post-consumption).

\section{Determinants of customer satisfaction}

Customer satisfaction has become a fundamental goal of all business organisations; this position is derived from long held conviction that for a firm to be profitable, it must satisfy customers (Shin and Elliott, 2001; Ranaweera and Prabhu, 2003). Generally, academics and business practitioners have long admitted that customer satisfaction is one of the highest priorities of business organizations and research have also shown that customer satisfaction is a key determinant in maintaining and sustaining business relationship (Oliver, 1997; Ahmad, 2007; Rahim, 2016b). Essentially, customer satisfaction is influenced by overall quality/price expectations (Anderson, 1994), firm's image (Aga and Okan, 2007), and persons' desires (Spreng, MacKenzie and Olshavsky, 1996). According to Oliver (1997), the determinants of customer satisfaction can be categorized into: instrumental factors (the performance of the physical product) and expressive factors (the psychological performance of the product). He later maintained that for customer's to be satisfied, the product or service must meet expectations on both instrumental and expressive outcomes.

\section{Perspectives on customer loyalty}

The term "loyalty" has its direct philological origin in old French word, however, its older linguistic roots comes from the Latin word "Fidelis" (Stanford Encyclopedia of Philosophy, 2013). In service domain, loyalty has been conceptualized in an extensive form such as "observed behaviors"; these behavioural expressions according to Caruana (2002) relate to the brand not just thoughts. Largely, it is difficult to advance a universal definition of customer loyalty as it has been defined and measured in a myriad of ways too numerous for a single study to completely discuss. From a general viewpoint, loyalty can be described as 
the response consumer's exhibit to brands, services, stores, or product categories (Uncles, Grahame and Kathy, 2003). According to Jones and Sasser (1995), measurement of customer loyalty falls into three phases: willingness to repurchase, primary behaviour (transaction information) and secondary behaviour (tendency to recommend products and services).

Yang, Jun and Paterson (2004) also indicate that loyal customers have the propensity to shun searching, locating, and evaluating competing brands; which predispose them to be loyal to a particular organisation. Therefore, a loyal customer is one who holds a favourable attitude toward the organisation, recommends the firm to other consumers and displays consistent repurchase behaviour (Dimitriades, 2006). According to Oliver (1997), loyalty is a dedication on the part of the buyer to uphold a relationship and a commitment to buy the product or service repeatedly. Therefore, loyalty encompasses a behavioral element which suggests a repurchase plan but also comprises an attitudinal constituent which is based on preferences and impression of the customers (Sheth and Mittal, 2004). However, some scholars support the view of customer loyalty from three perspectives: behavioural loyalty, attitudinal loyalty, and a composite approach of behavioural and attitudinal loyalty (Ahmad, 2007).

Loyalty status at any point is influence by diverse factors collectively referred to as loyalty supporting and repressing factors (Bendapudi and Berry, 1997). Loyalty-supporting factors are those components (customer satisfaction, commitment etc.) that work to sustain or enhance customer loyalty (Nordman, 2004). Loyalty repressing factors, on the other hand, decrease customer loyalty status by causing disloyal behaviour (Nordman, 2004). These factors include, poor product quality, failure to keep to service promises, poor company reputation, and poor response to service failure among others.

\section{Is Customer Satisfaction an indicator of Customer Loyalty?}

Several scholars speculate that customer satisfaction is an important factor in explaining loyalty behaviour (Bendapudi and Berry, 1997; Eriksson and Vaghult, 2000; Rahim et al., 2012). However, within the same firm or industry, different customers could have diverse needs, goals and experiences that influence their expectations. On this note, Pizam and Ellis (1999) maintain that customer satisfaction is a psychological impression and not a universal phenomenon, which suggests that not all customers acquires similar satisfaction level out of related purchase or service encounter. The view that customer satisfaction leads to loyalty is founded on the evidence that by growing customer satisfaction, customers are likely to remain loyal to the service provider (Eriksson and Vaghult, 2000). Similarly, it is also not out of context to expect that dissatisfied customers are more prone to terminate a business relationship than satisfied customers, however, growing reservations have develop that satisfaction alone is enough to evaluate customer loyalty (Andreas, 2010).

According to Shaw (cited in Ferreira, Faria, Carvalho, Assuncao, Silva and Ponzoa, 2013), loyalty is a seductive manifestation or rationality, which may not automatically reflect reality. In line with the above claims, Yu-Kai (2009) elucidates on the relationship between customer satisfaction and loyalty and states that it is possible in some occasions for customers to display loyalty tendency without being exceedingly satisfied (e.g. when there are few substitutes) and to be extremely satisfied and yet not loyal (i.e. when many substitutes are available). Against the aforementioned backdrops, a number of scholars have questioned the declaration that customer satisfaction is a driver of customer loyalty and instances have been documented where customer satisfaction and loyalty do not always relate positively (Oliver, 1997; Egan, 2004; Pritchard and Silvestro, 2005). For instance, Oliver (1999) notes that despite customer satisfaction many businesses still experience high rate of customer churning. Hence, satisfaction alone does not indicate customer loyalty, because it may not sufficiently expose how vulnerable company's customers are to switching behaviour (Coyles and Gokey, 2002). On this note, Reichheld (2006) appeals that until all available options are 
unearthed; it can be rightly argued that existing customers can only express their disposition towards an organisation's product/service, but not their loyalty status in totality. Consequently, the notion that customer satisfaction leads to loyalty hold in some situation, but the affirmation seems less reassuring in some context and is therefore, far from being considered a widespread philosophy (Egan, 2004).

\section{Research methodology Research Design}

This study used the correlation research design because the intended purpose of the research was to investigate the relationship between the variables under investigation. According to Fraenkel and Wallen (2000), correlation research describes the nature of relationship between variables and provide basis for ascertaining the nature and strength of relationship between variables of interest. The main research paradigm adopted in this study is the positivistic paradigm. The choice of this research paradigm hinged on the fact that the study views the phenomena under investigation as a reality that should be analysed objectively, more importantly, most research work related to this study have been done using positivist paradigm (Whyte, 2011).

\section{Study area}

This study was undertaken at the two domestic airports in Lagos State, Nigeria (Murtala Muhammed Terminal One and Murtala Muhammed Airports Two). Currently, there are twenty three (23) Domestic Airports in Nigeria. Nonetheless, most of the airlines operating in the domestic market fly to and from the two selected airports; hence, the choice of the airports is based on the fact that they serve as hubs of domestic airline operations in Nigeria (National Bureau of Statistics-NBS, 2014). Similarly, in comparison to the other domestic airports, Murtala Muhammed Terminal One and Murtala Muhammed Airports Two in Lagos state remain the busiest airports. Report released by NBS (2014) on domestic passengers' traffic revealed that in 2013 , Lagos airports gained 231,016 or $6.33 \%$ more passengers, bringing its annual total to $3,877,840$ which is equivalent to $38.49 \%$ of the total load factor in Nigeria domestic air transportation. The upsurge can be attributed to increased flight routes and the emergence of new airline operators in Nigeria. All the selected airlines in this study cover all the major domestic airports which spread across six geo-political zones in Nigeria (North-Central, North-East, North-West, South-East, South-South, and South-West) within the period of the survey. Although year on year, air craft movement and passengers traffic both domestic and international passenger numbers were lower in Nigeria (NBS, 2015). According to the statistics released by NBS (2014), domestic passengers' traffic by domestic airports ranked Lagos as the first follow by Abuja, Port Harcourt, Owerri, and Kano.

\section{Variables and measurements}

In this study, customer satisfaction is the independent variable, while, customer loyalty, is the dependent variable. A review of literature proposes that satisfaction scale of De-Wulf, Odekerken-Scroder and Lacobucci, (2001) is one of the most comprehensive and widely used measures of customer satisfaction in marketing research (Ahmad, 2007). On this note, this study adapted satisfaction scale of De-Wulf et al., (2001) because it has proved to be valid in different countries and across industries (Ahmad, 2007). Thus, customer satisfaction was measured with seven items (which include overall and relative satisfaction items). Similarly, this study, adapted Too et al., (2001) loyalty measurement scale which measures customer loyalty as a multi-dimensional construct. A total of eight items were used to measure customer loyalty. In particular, four of these items reflect each of behavioural, and attitudinal measure of loyalty. Consequently, questionnaires items were created in the light of the two variables, based on multi-item scales. The response options for all the items 
generated to measures these variables was based on 7 point Likert-scale with end points of "strongly disagree" (1) and "strongly agree" (7).

\section{Population of the study}

The target population of this study was the air passengers who travelled from Lagos with any of the selected domestic airlines (Arik Air, Aero Contractors, First Nations Airways, Overland Airways, Dana Air, and Med-view Airline) to any domestic destination in Nigeria from the two airports. The selected airlines covered in this study have been operating in Nigeria for quite a reasonable number of years, and with relatively high number of routes compared to those that are excluded from the study. The two airlines exempted (discovery airline and Azman airline services limited) were relatively new in the Nigerian airline industry as at the time the survey was carried out.

\section{Sample selection and technique}

The sample of this study consisted of 600 air passengers departing with the selected airlines to any destination in Nigeria. A non-probability convenience sampling was used to distribute questionnaires to the respondents. According to Starmass (2007), the benefits of convenience sampling are low cost and time saving; which is most comfortable for study with homogeneous population. A total of 496 copies of questionnaire were distributed, 18 were not returned, and a total of 383 were found useful and valid for data analysis. Thus, the response rate was $77.22 \%$.

\section{Method of data collection}

This study is empirical and considered primary and secondary data sources. Primary data were mainly obtained through the questionnaires, while secondary sources emanated from previous published studies such as journal, theses, conference proceedings, working papers etc. that are relevant to the phenomena under investigation. Self-administered questionnaires was chosen as method of data collection because, it guarantee respondents privacy, which may encourage them to objectively disclose their true feelings and perceptions (Cooper and Schindler, 2011), and because of its attendant cost-effectiveness (Struwig and Stead, 2001). The survey questionnaire consisted of closed-ended questions on the following aspects: customer satisfaction, customer loyalty, and travel behaviour.

\section{Pilot testing and questionnaire administration}

A pilot study was conducted to check for vagueness and ambiguities in the questionnaire. Prior to the pilot study, the questionnaire was given to three marketing academics in the department of Business Administration, University of Lagos to peruse the instrument. Adjustments were made to the final questionnaire as suggested by them. The questionnaire was then piloted to test for reliability. The questionnaire was pre-tested among 30 air travellers three weeks to the main study. The reliability of the survey instrument was computed using Cronbach's alpha coefficients (see Table 1). As shown in Table 1, the reliability coefficient for the two variables exceeded the cut-off of $\alpha=0.70$. Hence, the measurement instrument was adjudged to be reliable (Girden, 2001).

Given the voluntary nature of the study, data were collected from the respondents directly by the researcher with the help of six research assistants. In order to ensure representativeness of the samples, the questionnaires were completed during the weekdays and weekends by the passengers waiting to board their flights at the two airports in Lagos state. Only departing passengers were included in the survey because, arriving passengers have very limited time to stay at the airport. The fieldworkers approached the passengers waiting at the departure point to discussed the purpose of the survey and solicit for their cooperation. 


\section{Analytic approach}

The data collected from the respondents was edited, coded, captured and presented on Microsoft Excel prior to data analysis. For data processing, statistical techniques including descriptive statistics (frequency, percentages, mean and standard deviation) were computed. Hypotheses were tested using Pearson correlation analysis, regression analysis and Anova.

\section{Hypotheses testing and discussion Hypothesis one}

There is no significant relationship between customer satisfaction and loyalty in Nigerian domestic airline industry.

Table 1: Descriptive statistics and Reliability test

\begin{tabular}{|l|l|c|c|c|c|}
\hline S/No & Variables & No. of items & $\alpha$ & Mean & Std. Deviation \\
\hline 1. & Customer satisfaction & 7 & .822 & 3.26 & .368 \\
\hline 2. & Customer loyalty & 8 & .780 & 3.18 & .383 \\
\hline
\end{tabular}

Source: Field Survey, 2014, Note (7-point Likert scale was used)

Descriptive statistics and reliability test scores of the two variables investigated in this study are summarized in Table 1. The two variables have satisfactory reliability values as indicated by Cronbach's Alpha values exceeding $\alpha=.70$. It is also clear from Table 1 , that the mean and the standard deviations scores of the two variables are relatively low. Which imply poor satisfaction and loyalty on the part of air passengers'.

Table 2: Correlation Matrix Customer satisfaction and loyalty

\begin{tabular}{|l|l|c|c|}
\hline Variables & & Customer satisfaction & Customer loyalty \\
\hline \multirow{3}{*}{$\begin{array}{l}\text { Customer } \\
\text { satisfaction }\end{array}$} & Pearson Correlation & 1 & $.774^{\star *}$ \\
\cline { 2 - 4 } & Sig. (2-tailed) & & .000 \\
\cline { 2 - 4 } & $\mathrm{N}$ & 383 & 383 \\
\hline \multirow{3}{*}{ Customer loyalty } & Pearson Correlation & $.774^{\star *}$ & .000 \\
\cline { 2 - 4 } & Sig. (2-tailed) & & 383 \\
\cline { 2 - 4 } & $\mathrm{N}$ & 383 & \\
\hline
\end{tabular}

${ }^{* *}$ Correlation is significant at 0.01 levels (2-tailed) and $N=383$

Source: Field Survey, 2014

To examine the relationship between customer satisfaction and loyalty, Pearson correlation analysis was applied to determine the direction and strength of relationship between the two variables. Table 2 displays the correlation between customer satisfaction and loyalty. There exists a statistically significant positive high correlation between customer satisfaction and customer loyalty $(r=.774, n=383, p<0.01)$, with high levels of coefficient of determination between the two variables (59.91\%). As shown in Table 2, the patterns of correlation between the two variables reveal that they have a valid significant relationship.

Table 2 also shows that the two variables vary together approximately $60 \%$ of the time and they appear to be independent of each other by $40 \%$ of the time. Furthermore, linear regression analysis was run to examine the predictive influence of customer satisfaction on loyalty among domestic airline passengers in Nigeria. Table 3 shows the results of regression analysis between independent variable (customer satisfaction) and dependent variable (customer loyalty). Basic assumptions of the regression analysis (such as linearity, collinearity, condition index, Dubin-Watson etc.) reveal that the data were suitable for running regression analysis. Table 3 also demonstrates that the model explain $59 \%$ of 
variation in customer loyalty $\left(\mathbf{R}=\mathbf{. 7 7 4}, \Delta \mathbf{R}^{2}=.599, \mathrm{t}=\mathbf{2 3 . 8 7 5}, \mathrm{p}=\mathbf{. 0 0 0}\right.$, where $\left.\mathrm{p}<0.05\right)$. From the above accounts, hypothesis one which states that there is no significant relationship between customer satisfaction and loyalty in Nigerian domestic airline industry is not supported by the finding of this study. From the foregoing, it can be concluded that customer satisfaction exerts significant effect on customer loyalty. This indicated lack of support for hypothesis one. The finding of this study is in line with the study conducted by Bendapudi and Berry (1997), Eriksson and Vaghult (2000), Nor and Wan (2013) and Rahim (2015). However, the finding contradicts that of Egan (2004), Pritchard and Silvestro (2005) and Andreas (2010) whose studies documented insignificant relationship between customer satisfaction and loyalty.

Table 3: Regression of customer satisfaction with customer loyalty

\begin{tabular}{|l|c|c|c|c|c|c|c|}
\hline & Beta $(\beta)$ & t-value & p-value & $\mathbf{R}$ & $\mathbf{R}^{2}$ & F-value & F-sig \\
\hline Model & & 9.882 & .000 & .774 & .599 & 570.039 & .000 \\
\hline Constant & & 23.875 & .000 & & & & \\
\hline Customer loyalty & .774 &
\end{tabular}

Predictors: (Constant), Customer satisfaction

Dependent variable: Customer loyalty

Source: Field Survey, 2014

\section{Hypothesis two}

Compared with infrequent travellers, frequent air passengers are not likely to display more loyalty tendency in Nigerian domestic airline industry.

Table 4: Descriptive statistics - frequent and non-frequent air passengers

Source: Field Survey, 2014

\begin{tabular}{|l|c|c|c|}
\hline \multicolumn{1}{|c|}{ No of Flights } & $\mathbf{N}$ & Mean & Std. Deviation \\
\hline 3 - 4 times & 109 & 3.20 & .372 \\
\hline 5 -6 times & 167 & 3.25 & .346 \\
\hline More than 7 times & 107 & 3.33 & .391 \\
\hline
\end{tabular}

The travel behaviour (in term of number of flights engaged by air passengers) is depicted in Table 4. As shown in Table 4, the overall sampled passengers (383) was separated into three sub-samples (groups) according to the number of flights they had taken with the selected airlines from October, 2013 to October, 2014 when the survey was conducted. The first cluster (109 passengers) consisted of those who had flown with the selected airlines between (3-4 times), the second groups (167 passengers) those who travelled (5-6 times), and the third set (107 passengers) those who flew more than 7 times. For tenacity and purpose of analysis, the first two clusters are referred to as "non-frequent travellers" and the last category as frequent travellers. As depicted in Table 4, passengers who flew between 3-4 times and 5-6 times (infrequent travellers- by this study classification) displayed slightly lower loyalty tendency to the airlines, as indicated by their mean scores while those who have travelled more than 7 times have demonstrated slightly higher loyalty level to the airlines.

To decide whether frequent travellers, compared to infrequent travellers are not likely to display more loyalty tendency in Nigerian domestic airline industry; One-way analysis of variance was conducted. As shown in Table 5, loyalty tendency of frequent air travellers is significantly different compared to infrequent travellers $F(2,380)=3.489, p<0.05$. Although the mean score across the three clusters of travellers varies slightly, however, Post-hoc comparisons using Turkey-Highly Significant Difference (HSD) test revealed that the mean score of those that flew between 3-4 times was significantly different from those that flew 
more than 7 times, while those that flew 5-6 times did not differ significantly from either those that flew 3-4 times and more than 7 times. Furthermore, the low Eta squared value of 0.02 was too small; which reveals that the results is independent of sample size effects and provides further evidence for the rejection of hypothesis two. Based on the above results, hypothesis two which states that compared with infrequent travellers, frequent air passengers are not likely to display more loyalty tendency in Nigerian domestic airline industry is not supported. Hence, the study concludes that frequent travellers are likely to display more loyalty tendency towards domestic airline carriers than non-frequent air travellers.

Table 5: ANOVA-loyalty level of infrequent and frequent air passengers

\begin{tabular}{|l|c|c|c|c|c|}
\hline & Sum of Squares & Df & Mean Square & F & Sig. \\
\hline Between Groups & .929 & 2 & .464 & 3.489 & .032 \\
\hline Within Groups & 50.857 & 380 & .134 & & \\
\hline Total & 51.786 & 382 & & & \\
\hline
\end{tabular}

Source: Field Survey, 2014

\section{Conclusion}

This study investigates the interrelationships and effects between customer satisfaction and loyalty in Nigerian domestic airline industry. The finding of this study reveals that customer satisfaction is strongly related and has potential to enhance passenger loyalty towards the airline. Finding of the study also reveal that frequent travellers displayed more loyalty tendency to airline operators than non-frequent air passengers. Although, there are many tactics for building and nurturing loyalty in the airline industry, passengers' satisfaction with the service quality offered by airline has been documented as the most influential strategies. Therefore, airline operators should implement proactive strategies and strive for long-term relationship with customers by providing service quality that will enhance customer satisfaction. Aside from the capability to enhance passenger loyalty towards the airline, customer satisfaction leads to other important benefits such as favourable word-of-mouth communication (David and Dina, 2009), likelihood of receiving fewer complaints (Kang, Zhang and Zheng, 2009) which are very important to airline survival.

Despite high statistical significant correlation between customer satisfaction and loyalty, the finding of this study reveals that customer loyalty may be dependent on several other independent variables (such as price, perceived values, brand image, individual psychological and sociological features among others). In other words, factors other than improvement in customer satisfaction level may influence customer loyalty in the airline industry (because almost $40 \%$ change in customer loyalty level is influenced by factors other than passengers' satisfaction- as shown in Table 3). The finding that the loyalty level of infrequent fliers compared to frequent travellers is significantly different, affirm the view that loyal customer repurchase more often which further dictates the need to continually enhance their flight experience and satisfaction in the airline industry. However, Caruna (2002) maintains that a behavioural standard (such as repeat purchase) has limited potency to predict loyalty status, due to lack of conceptual basis of a dynamic process. For instance, the relatively low frequency patronage may be connected to other factors, such as non-availability of prefer airline, prefer flight schedule/duration or restrictions imposed by the regulatory authority (sanction). From this viewpoint, loyalty status more often than not may fail to account for comprehensive and fundamental causes of loyalty behaviour (Alok and Srivastava, 2013; Sharp, Anne and Malcolm, 2015). 


\section{References}

Adee, A. (2004). 'Antecedents and consequences of Student satisfaction with University Services: A longitudinal analysis'. Academy of Marketing Studies Journal, January, 2004.

Aga, M., Okan, V.S. (2007). 'An empirical investigation of service quality and customer satisfaction in professional accounting firms: Evidence from North Cyprus'. Problems and Perspectives in Management, vol. 5, no. 3, pp. 84-96.

Ahmad, B.S. (2007). Evaluating an extended relationship marketing model for Arab guests of Five-Star hotels. Ph.D. Thesis, School of Hospitality, Tourism and Marketing, Faculty of Business and Law, Victoria University, Melbourne. available from: http://www.vuir.vu.edu.au/511/shammout.ped. [20.03.2013].

Alok, K.R., Srivastava, M. (2013). 'The antecedents of customer loyalty: An empirical investigation in Life Insurance Context'. Journal of Competitiveness, vol. 5, no. 2, pp. 139-163,

Anderson, E.W. (1994). 'Cross-category variation in customer satisfaction and retention'. Marketing Letters, vol. 5, no. 1, pp. 19-30.

Andreas, A. (2010). 'Verifying alternative measures of the service-quality construct: Consistencies and contradictions'. Journal of Marketing Management, vol. 26, no. 5/6, pp. 570-587.

Bendapudi, N., Berry, L.L. (1997). 'Customers' motivations for maintaining relationships with service providers'. Journal of Retailing, vol. 73, no. 1, pp. 15-37.

Bejou, D., Palmer, A. (1998). 'Service failure and loyalty: An exploratory empirical study of airline customers'. Journal of Services Marketing, vol. 12, no. 1, pp. 7-22.

Caruana, A. (2002). 'Service loyalty: The effects of service quality and the mediating role of customer satisfaction'. European Journal of Marketing, vol. 36, no. 7/8, pp. 811-822.

Chang, H.H., Wang, Y.H., Yang, W.Y. (2009). 'The impact of e-service quality, customer satisfaction and loyalty on e-marketing: Moderating effect of perceived value'. Total Quality Management, vol. 20, no. 4, pp. 423-443

Cooper, D.R., Schindler, P.S. (2011). 'Business research methods' $\left(11^{\text {th }}\right.$ eds.). New York: McGraw-Hill//rwin.

Coyles, S., Gokey, T. (2002). 'Customer retention is not enough'. The McKinsey Quarterly vol. 2, no. 18, Sept. 2002.

David, G., Dina, M. (2009). 'Firm-created word-of-mouth communication: Evidence from a field test'. Marketing Science, vol. 28, no. 4, pp. 721-739

De-Wulf, K., Odekerken-Scroder, G., Lacobucci, D. (2001). 'Investments in consumer relationships: A cross-country and cross-industry exploration'. Journal of Marketing, vol. 65, no. 4 , pp. 33-50.

Dimitriades, S.Z. (2006). 'Customer satisfaction, loyalty and commitment in service organizations: Some evidence from Greece'. Management Research News, vol. 29, no. 12, pp. 782-800.

Egan, J. (2004). Relationship marketing: Exploring relational strategies in marketing $\left(2^{\text {nd }}\right.$ eds.). Harlow: Pearson Education Ltd.

Eriksson, K, Vaghult, A.L. (2000). 'Customer retention, purchasing behaviour and relationship substance in professional services'. Industrial Marketing Management, vol.29, no. 4, pp. 363-372.

Ferreira, P., Faria, S., Carvalho, V., Assuncao, J., Silva, A., Ponzoa, E. (2013). Consumer behaviour in retail: Online and offline-what is the future? International Conference on Marketing and Consumer Behaviour, available from: http://www.academia.edu/Consumer behaviour in Retail online and offline.pdf. [23.08.2014]. 
Fraenkel, J.R., Wallen, N.E. (2000). How to design and evaluate research in education (4th ed.). New York: McGraw-Hill.

Garbarino, E., Johnson, M.S. (1999). 'The different roles of satisfaction, trust, and commitment in customer relationships'. Journal of Marketing, vol. 63 (April), pp. 70-87.

Giese, J.L., Cote, J.A. (2002). 'Defining consumer satisfaction'. Academy of Marketing Science Review, vol. 2, no. 1, pp. 1-24.

Gilbert, D., Wong, R.K. C (2003). 'Passenger expectations and airline services: A Hong Kong based study'. Tourism Management, vol. 24, pp. 519-532.

Girden, E.R. (2001). Evaluating research articles ( $2^{\text {nd }}$ eds.). London: Sage Publications.

Gronholdt, L., Martensen, A., Kristensen, K. (2000). 'The relationship between customer satisfaction and loyalty: Cross-industry differences'. Total Quality Management, vol. 11, no. 4-6, pp. 509-514

Helson, H. (1964). Adaptation-level theory. New York: Harper and Row.

Hill, N., Alexander, J. (2000). Handbook of customer satisfaction and loyalty measurement $\left(2^{\text {nd }}\right.$ eds.). England: Gower Publishing Ltd.

Huang, Y.K., Feng, C.M. (2009). 'Why customers stay: An analysis of service quality and switching cost on choice behaviour by Catastrophe Model'. International Journal of Services Operations and Informatics, vol. 4, no. 2, pp. 107-122.

lacobucci, D., Grayson, K.A., Ostrom, A.L. (1994). 'The calculus of service quality and customer satisfaction: Theoretical and empirical differentiation and integration'. Advances in Services Marketing and Management, vol. 3, no. 1, pp. 67.

Jones, T.O., Sasser, E. (1995). 'Why satisfied customer defect'. Harvard Business Review, vol. 73, no. 6, pp. 88-99.

Kang, J., Zhang, X., Zheng, Z. (2009). 'The relationship of customer complaints, satisfaction and loyalty: Evidence from China's mobile phone industry'. Journal of Marketing, vol. 8, no. 12, pp. 22-36.

Kotler, P. (2001). Marketing management $\left(10^{\text {th }}\right.$ eds.). London: Prentice Hall International Editions.

McGill, A.L., lacobucci, D. (1992). 'The role of post-experience comparison standards in the evaluation of unfamiliar services'. Advances in Consumer Research. vol. 19, 570- 578.

Miller, J.A. (1977). Studying satisfaction, modifying models, eliciting expectations, posing problems, and making meaningful measurements. In H.K. Hunt (Eds,). Conceptualization and measurement of consumer satisfaction and dissatisfaction. (pp. 72-91). Bloomington, IN: Indiana University School of Business.

Mittal, V., Kamakura, W.A. (2001). 'Satisfaction, repurchase intent, and repurchase behaviour: Investigating the moderating effect of customer characteristics'. Journal of Marketing Research, vol. 38, no. 1, pp. 131-142.

Nadiri, H., Hussain, K., Ekiz, E.H., Erdogan, S. (2008). 'An investigation on the factors influencing passengers' loyalty in the North Cyprus national airline'. TQM Journal, vol. 20, no. 3, pp. 265-280.

National Bureau of Statistics (2014). Nigerian Aviation Sector-Summary report of passenger traffic: 2010-2013 and Quarter One 2014. Available from: http://www.nigeriastat.gov.ng. [20.05.2014,]

National Bureau of Statistics (2015). Nigerian Aviation Sector- Summary Report: Q2, 2015. available from: http://www.nigeriastat.gov.ng. [24.11.2016],

Nor, K.A., Wan, N.M. (2013). 'Perceptions of service quality and behavioural intentions: A mediation effect of patient satisfaction in the private health care in Malaysia'. International Journal of Marketing Studies, vol. 5, no. 4, pp. 15-29

Nordman, C. (2004). Understanding customer loyalty and disloyalty-The effect of loyalty supporting and re-pressing factors. Doctoral Thesis No. 125, Swedish School of economics and Business Administration, Helsinki, Finland, available from: http://www. Faculty.mu.edu.saidownload.pap?fid=50833.pdf. [20.05.2013]. 
Oliver, R.L. (1977). 'Effect of expectation and disconfirmation on post exposure product evaluations: An alternative interpretation'. Journal of Applied Psychology, vol. 62, no. 4, pp. 480-486.

Oliver, R.L. (1980). 'A cognitive model of the antecedents and consequences of satisfaction decisions'. Journal of Marketing Research, vol. 17 (November), pp. 460-490.

Oliver, R.L. (1997). Satisfaction: A behavioural perspective on the consumer. New York: Irwin/McGraw-Hill.

Oliver, R.L. (1999). 'Whence customer loyalty?' Journal of Marketing, 63, 33-44.

Patterson, P.G. (1993). 'Expectations and product performance as determinants of satisfaction for a high-involvement purchase'. Psychology Marketing, vol. 10, no. 5, pp. 449-466.

Peyton, R.M., Pitss P.S., Kamery, R.H. (2003). Consumer satisfaction/dissatisfaction $(C S / D)$ : A review of the literature prior to the 1990s. Proceedings of the Academy of Organizational Culture, Communications and Conflicts, vol. 7, no. 2. Allied Academies International Conference. Las Vegas. pp. 41-46.

Pizam, A., Ellis, T. (1999). 'Customer satisfaction and its measurement in hospitality enterprises'. International Journal of Contemporary Hospitality Management, vol. 11, no. 7, pp. 326-339.

Pritchard, M., Silvestro, R. (2005). 'Applying the Service Profit Chain to analyse retail performance: The case of the Managerial Strait-jacket?' International Journal of Service Industry Management, vol. 16, no. 4, pp. 337-356.

Rahim, A.G., Ignatius, I.U., Adeoti, O.E. (2012). 'Is customer satisfaction an indicator of customer loyalty?' Australian Journal of Business and Management Research, vol. 2, no. 07, pp. 14-20.

Rahim, A.G. (2015). Customer satisfaction and loyalty towards perceived service quality of domestic airlines in Nigeria. Unpublished Doctoral Thesis, University of Lagos, Lagos.

Rahim, A.G. (2016a). 'Perceptions of service quality: An empirical assessment of modified SERVQUAL Model among Domestic Airline Carriers in Nigeria'. Acta University Sapientiae, Economics and Business, vol. 4, pp. 5-31

Rahim, A.G. (2016b). 'Perceived service quality and customer loyalty: The mediating effect of passenger satisfaction in the Nigerian Airline Industry'. International Journal of Management and Economics, vol. 52, October-December 2016, pp. 94-117

Ranaweera, C., Prabhu, J. (2003). 'On the relative importance of customer satisfaction and trust as determinants of customer retention and positive word of mouth'. Journal of Targeting, Measurement and Analysis for Marketing, vol.12, no. 1, pp. 82-98.

Reichheld, F. (2006). The ultimate question: Driving good profits and true growth (pp.1-28). Boston, Massachusetts: Harvard Business School Publishing Corporation.

Reichheld, F.F., Sasser, Jr., W.E. (1990). 'Zero defections: Quality comes to service'. Harvard Business Review, (September-October), pp. 105-111.

Reichheld, F.F. (1996). 'Learning from customer defections'. Harvard Business Review, (March/April), pp.56-69.

Samaha, S.A., Palmatier, R.W., Dant, R.P. (2011). 'Poisoning relationships: Perceived unfairness in channels of distribution'. Journal of Marketing, vol. 75, pp. 99-117.

Sharp, B., Anne, S., Malcolm, W. (2015). Questioning the value of the "True" brand loyalty distinction. Marketing Science Centre, University of South Australia, available from: https://www.marketingscience.info/wp-content/uploads/staff/2015/08/6427.pdf.

[12.11.2014].

Sheth, J.N., Mittal, B. (2004). Customer behavior: A managerial perspective (2 ${ }^{\text {nd }}$ eds.). Mason, Ohio: Thomson/South-Western

Shin, D., Elliott, K.M. (2001). 'Measuring customers' overall satisfaction: A multi-attributes assessment'. Services Marketing Quarterly, vol. 22, no. (1), pp. 3-19. 
Spreng, R.A., MacKenzie, S.B., Olshavsky, R.W. (1996). 'A reexamination of the determinants of consumer satisfaction'. Journal of Marketing, vol. 60, no. 3, pp. 15- 32.

Stanford Encyclopedia of Philosophy (2013). Loyalty, available from http://www. platostanford.edu/entries/loyalty/pdf. [24.12.2014].

StarmassInternational (2007). Your key to business success in China, available from: http://www.starmass.com/en/research sampling method.htm. [24.12.2014].

Struwig, F.W., Stead, G.B. (2001). Planning, designing and reporting research. Cape Town: Pearson Education South Africa.

Swan, J.E., Oliver, R.L. (1989). 'Post-purchase communications by consumers'. Journal of Retailing, vol. 65, no. 4, pp. 516-553.

Taylor, T.B. (1998). 'Better loyalty measurement leads to business solutions'. Marketing News, vol. 32, no. 22, pp. 41-42.

Tim, K., Lerzan, A., Alexander, B., Luke, W. (2009). 'Why a loyal customer isn't always a profitable one'. The Wall Street Journal, (Monday June 22, 2009), CCL111(144).

Timothy, L.K., Bruce,C., Lerzan, A., Tor, W.A., Jay, W. (2007). 'The value of different customer satisfaction and loyalty metrics in predicting customer retention, recommendation and share-of-wallet'. Managing Service Quality, vol. 17, no. 4, pp. 361-384.

Too, H.Y., Souchon, A.L., Thirkell, P.C. (2001). 'Relationship marketing and customer loyalty in a retail setting: A dyadic exploration'. Journal of Marketing Management, vol. 17, no. 1, pp. 89-93.

Uncles, M.D., Grahame, D.D, Kathy, H. (2003). 'Customer loyalty and customer loyalty programs'. Journal of Consumer Marketing, vol. 20, no. 4, pp. 294-317.

Vavra, T.G. (1997). Improving your measurement of customer satisfaction: A guide to creating, conducting, analyzing, and reporting customer satisfaction measurement programs. American Society for Quality.

Whyte, R.D. (2011). Strategic windows: Australian European Union "open skies" agreement creates new entrant oppourtunity for long-haul low cost- airline model. Ph.D. Thesis, James Cook University, available from http://www.eprints.JCU.edu.au/23470. [24.06.2014].

Yang, Z., Jun, M., Peterson, R.T. (2004). 'Measuring customer perceived online service quality'. International Journal of Operations and Production Management, vol. 24, no. 11, pp. 1149-1174.

Yi, Y. (1990). A critical review of consumer satisfaction. In V. Zeithaml, (Eds.). Review of marketing (pp. 68-123). Chicago, IL: American Marekting Association.

Yu-Kai, H. (2009). 'The effect of airline service quality on passengers' behavioural intentions using SERVQUAL scores: A Taiwan case study'. Journal of the Eastern Asia Society for Transportation Studies, vol. 8, pp. 1-17.

\section{Bio-note}

Rahim Ajao Ganiyu is lecturer in the Department of Business Administration, University of Lagos, Nigeria. Rahim moved into academic in 2016 with over 12 years industrial working experience in different industries/tasks. His employment experiences were primarily in marketing of industrial goods, oil and gas and property consulting. His research has been published in local and international journals. His areas of research interest include service quality, brand management, entrepreneurship, relationship marketing, project management, change management, consumer behavior, and development studies. 